\title{
Ri'e Hikun Liman Wanan Communication Media with Rera Wulan Tana Ekan
}

\author{
DOI: https://doi.org/10.47175/rielsj.v1i1.34
}

\author{
${ }^{1,2}$ Teaching and Education \\ Faculty of Flores Ende \\ University, Indonesia \\ ${ }^{*}$ Corresponding Email: \\ Yosefdemon86@gmail.com
}

| Yosef Demon ${ }^{1, *}$ | Veronika Genua ${ }^{2}$ |

\begin{abstract}
The traditional people's belief in God as the Supreme Cause of the universe can be expressed in various ways. The methods used are the inner representation of traditional society of the existence of a God who created the heavens and the earth. The Lamaholot people refer to God as Rera Wulan Tana Ekan 'Creator of Heaven and Earth' in a cultural perspective. Rera Wulan Tana Ekan in the perspective of Lamaholot culture is the Highest Being who is believed to have perfect abilities such as creating, maintaining, maintaining, even destroying. These particularities of Rera Wulan Tana Ekan are the basis for the importance of intense communication between humans and Rera Wulan Tana Ekan God'. Ri'e Hikun Liman Wanan 'right hand corner of the house' is a medium of human communication with Rera Wulan Tana Ekan 'God'.

KEYWORDS

Supreme Cause; cultural perspective; Rera Wulan Tana Ekan; Ri'e Hikun Liman Wanan.
\end{abstract}

\section{INTRODUCTION}

Culture is a text about humans in all dimensions of their lives. These texts contain a track record of human habits from birth to death. This string of human habits forms a cycle called culture. So culture or culture is a complexity of human life that is related to knowledge, beliefs, art, morals and others. This is in line with Tylor's opinion in Syamsudin (2015, p . 26-27), which states that culture, 'is that complex whole which includes knowledge, beliefs, art, morals, law, custom, and any other capabilities, and habits acquired by man as a member of society".

Culture or culture is an abstraction of all human activities that are closely attached as a community. Culture is an abstract text but cultural activity shows the essence and existence that is rooted in the basic human joints and has been embedded since humans existed. Cultural inheritance is oral and hereditary. Humans always live and develop together with culture so it is not surprising that humans always adjust to every place wherever humans are. Humans are bound by a number of normative rules that are binding and regulating (Hoed, 2003, p. 143).

This paper is more sharp on the element of belief which is one part of culture. The belief referred to in this paper is the belief of the Lamaholot people in God as the Supreme Being or Creator of heaven and earth. God in the cultural context of Lamaholot is referred to as Rera Wulan Tana Ekan 'Creator of heaven and earth'. Rera Wulan Tana Ekan is an abstraction of Lamaholot's belief and recognition of God as a Substance who dwells on high.

Lamaholot community is an ethnic mix that is thick with culture. The Lamaholot community views culture as life and therefore life will continue if and only if humans are cultured. Everything related to the religious system cannot be understood in human terms, because the religious system is represented in the form of traditions, signs and symbols. 
Traditions, signs and symbols cannot be understood denotatively because all these signs cannot be reached by human reason but can only be believed to exist.

Rera Wulan Tana Ekan in the viewpoint of the Lamaholot community is something (animate) that has extraordinary abilities and very perfect traits such as, creating, organizing life, maintaining, guarding and even destroying '. Besides having the ability and perfect nature, Rera Wulan Tana Ekan lives in a high place that cannot be reached by anyone. As an invisible form of animate life, possessing extraordinary abilities, perfect nature and abiding in this high place which is the basis for the Lamaholot community creating a vertical relationship with God. The creation of this vertical relationship aims to facilitate communication with God.

The realization of this vertical relationship with God is represented in the form of a pillar which is one of the main pillars in a house. This connecting means in the Lamaholot tradition is called Ri'e Hikun Liman Wanan 'right hand corner of the house' (Bebe, 2012, p. 77). Why and how Ri'e Hikun Liman Wanan is used as a medium of communication with God will be discussed semiotic in this article.

Culture always utilizes symbols as human inner representation of what is thought and felt. Semenenko (2012, p. 22) states that culture is first and foremost as a semiotic system. This means that culture is a collection of semiotic symbols. In connection with the religious system in the community Lamaholot Ri'e Hikun Liman Wanan is a semiotic sign. As a semiotic sign, Ri'e Hikun Liman Wanan is interpreted straightforwardly as a medium of communication between humans and God. God in the perspective of Lamaholot culture is Rulan Wulan Tana Ekan 'Creator of heaven and earth'. Thus Rera Wulan Tana Ekan and Ri'e Hikun Liman Wanan is a sign, a marker and a sign that needs to be interpreted culturally as Lamaholot.

As for the religious rituals that show the strong belief of the Lamaholot community in the Rera Wulan Tana Ekan, such as Bau Lolon, 'the spilling of palm wine to the ground as an expression of gratitude', Lewak Tapo 'ritual splitting of coconut as a symbol of peace', Orek Warak 'the spiritual giving of names'. In addition to the rituals as mentioned, there are a number of symbols that represent the presence of the Supreme Being and ancestors such as, nuba nara or koke bale 'traditional house', oring bele 'cottage', eken matan pito 'bamboo with seven eyes, and nobo rorok 'stone throne'.

In connection with ri'e, Muda (2016, p. 93) states that talking about ri'e 'pillars, pillars', is talking about a sacred symbol. Ri'e in the cultural philosophy of Lamaholot is sacred, the study of religion must be based on religious belief in ancient religion. Ri'e Hikun Liman Wanan as a communication medium not only as a pole but includes a number of other suggestions that can not be separated such as, padu 'types of lighting made from a mixture of resin seeds and cotton', kenata 'bed', ekot 'place save betel vine, lime, gabe', neak 'a place for drinking made from coconut shell', kebako ' tobacco', kebia 'place for storing tobacco', tuak 'drink from palm trees', nawi 'container for filling palm wine made from bamboo'. This facility is integrated with the Ri'e Hikun Liman Wanan 'right hand corner of the house' as one communication medium.

In plain view and based on an understanding of human common sense, the right-hand corner of the house is one of the house's poles. The right-hand corner of the house becomes interesting and unique from the cultural point of view of Lamaholot. Why does it have to be a right-hand corner of the house and not a pole in another corner? Or why should the right corner pole and not the left corner pole of the house? Ri'e Hikun Liman Wanan is a medium of communication with God in the perspective of ancient religions while in Catholic religious beliefs Ri'e Hikun Liman Wanan is equivalent to the spiritual corner or corner of the family. If synchronized, it indicates that there is relevance between ancient religious beliefs with formal religion (Catholicism). 
The rapid development of science, technology and art in this milineal era poses a serious threat to the continuity of this tradition. Old cultures are considered highly irrelevant to modern and millennial lifestyles. Old traditions that are modest and normative, which regulate and bind and whose conditions of meaning and value of life are threatened with extinction because they are abandoned by the owner of culture..

\section{METHOD}

The qualitative descriptive method (Rukajat, 2018, p. 4-6) is the choice of the method used in this study. The technique used is the technique of proficiency, observation, documentation and note taking. Data analysis was performed using deductive-inductive or inductive deductive techniques, while the presentation of data was carried out informally, that is, the presentation was carried out using words (Suyanto, et al., p. 174).

\section{FINDING DISCUSSION}

\section{Finding}

The belief system in God in a community can be actualized in different ways. The Lamaholot community, for example, recognizes that God is in a high place far from the reach of humans who in Lamaholot culture are called Rera Wulan Tana Ekan. Rera Wulan Tana Ekan is understood as something (animate) that has perfect traits such as creating, preserving, preserving and even destroying -the nature and existence of Rera Wulan Tana Ekan is so important that communication with Rera Wulan Tana Ekan is very important.

This form of communication by utilizing the media in the form of Ri'e Hikun Liman Wanan. In a straightforward Ri'e Hikun Liman Wanan refer to the 'right-hand corner of the house' but culturally Ri'e Hikun Liman Wanan is an 'ancestor' which is used as a communication medium with Rera Wulan Wulan Tana Ekan 'God'. Ancestors are the subject of life so that treatment and respect for ancestors is carried out like living humans. The embodiment of the ancestors is represented in the form of Ri'e Hikun Liman Wanan, equipped with ritual facilities such as ekot, wua malu, apu, gabe, kebia, koli, kebako, nawing, tuak, neak, belayaldoi, belega, and padu. Every sign used has a cultural significance of Lamaholot.

\section{Discussion}

Ri'e Hikun Liman Wanan is a medium of communication between humans and God which is symbolic. The theory referred to is semiotic theory according to Pierce. Pierce in Sobur (2011, p. 6) states that the sign is associated with an object that has a similarity, its existence states the relationship of causality with the sign because of the convention with the sign. Understanding semiotics should use logic because logic allows one to think, connect and interpret the meaning of a sign. Linguistic signs are very important but not the only. Each sign that is used generally refers also to linguistic signs but not to all signs.

According to Kaelan (2009, p. 166) to perfect a concept, new words must be created. Pierce further states that symbols are something that represents someone for something. Something used to analyze a sign is called ground. So the sign is always in a triadic relationship that is ground, object and interpretant.

Signs are associated with ground and are distinguished from qualisign, sinsign, and legisign. Qualisign is the quality of signs such as, harsh words, loud sounds, weak sounds, soft sounds, and sweet sounds. Sinsign is the actual existence of objects or events that exist in sign. Words such as 'cloudy' and 'cloudy or in other words turbid river water indicate that there is rain in the downstream. Legisign is a norm contained by such as traffic signs that indicate various things that may or may not be human. 
Furthermore Pierce in Sobur (2006, p. 41) classifies interpretants into rheme, dicent sign or dicisign and argument. Rheme is a sign that allows people to interpret based on their choices for example, someone who blinks his eyes indicates that the person is crying or wants to sleep. Dicisign is in accordance with reality for example the increase in the frequency of traffic accidents, then on the side of the road mounted traffic signs stating that accidents often occur. Arguments are signs that directly give reasons about something.

Peirce describes the sign as 'something that represents something' (Sobur, 2009, p. 15). Interestingly that 'something' can be concrete (can be sensed) and then processed to represent 'something' that exists in human cognition. Signs are representations of what are marked.

Analysis and discussion of the data of the Ri'e Hikun Liman Wanan data utilizes Pierce's triadic (Representatmen, Object and Interpretant) as described below. Peirce states that something used to function is called a representatment. Signs associated with representatmen are grouped into qualisign, sinsign, and legisign. Based on the object the sign is divided into icons (icons), index (index) and symbol (symbol). Based on interpretant sign is divided into rheme, dicent sign or decisign, and argument.

The semiotic signs found in Ri'e Hikun Liman Wanan are:

\section{Representatmen}

Representation of signs in the form of visual appearance and verbs.Visual appearance and verb Ri'e Hikun Liman Wanan, the pole and its attributes. As one of the main pillars of housing, Ri'e Hikun Liman Wanan has different characteristics with three house poles at different angles. The representation is divided into:

a) Qualisign is the quality that is on the mark Ri'e Hikun Liman Wanan qualisign is a pole with a number of attributes such as, rie, kenata, ekot, wua malu, apu, gabe, tuak neak, nawi, kebia, koli kebako, lia me'a, belayaldoi, and padu. These features illustrate the distinctive features of these poles in contrast to other poles. Ri'e Hikun Liman Wanan plays vertically and is in the right corner of the house. This vertical position illustrates the vertical relationship between humans and the Supreme Being.

b) Sinsign is the actual existence of objects or events in the sign. Ri'e Hikun Liman Wanan will be ritualized with traditional ceremonies so that the Ri'e Hikun Liman Wanan becomes a media that is saved or sacred because it is at the place and at this pole that communication with the Supreme Being is carried out. Ritualisation made Ri'e Hikun Liman Wanan a liaison media between the Supreme Being and humans.

c) Legisign is the norm contained by the sign. Compliance and obedience to the uniqueness of this pole reminds all residents of the house or anyone to always act politely, speak politely and even think politely. The existence of liaison requires a person or group of people to be perfect in thinking, acting and speaking.

\section{Object}

Object is a sign that represents something in the form of experience, ideas or feelings. The object in the Ri'e Hikun Liman Wanan is one of the main pillars of housing. Ri'e Hikun Liman Wanan is a sign of the age that this is where all prayers and hopes are communicated with the Supreme Being. Experience proves that prayer and hope communicated through the Ri'e Hikun Liman Wanan are always granted. There is a feeling of calm, relief, comfortable and safe when communicating in this place at Ri'e Hikun Liman Wanan. Ri'e Hikun Liman Wanan is a representation of recognition of the existence of relations between humans and Rera Wulan Tana Ekan. Even though it is in a high place that cannot be reached, Rera Wulan Tana Ekan always hears all the gratitude, complaints, and hopes that are communicated by utilizing Ri'e Hikun Liman Wanan as a media. Object is divided into several parts, namely:

a) Icon 
Icon is a sign that states the relationship between signs and objects or references that are similar in nature. The right hand post of the house bears a resemblance to the other pillars which are both home owners. Some of the icons found on the right pole of this house such as: rie 'pole,pillar', kenata 'bed', ekot 'place of betel vein and areca nut', wua malu 'betel vein and areca nut', apu 'lime', gabe 'decoction of gambier leaves which the water is evaporated, printed round or square, used as a mixture of betel eats', tuak /nira 'palm wine', neak 'coconut shell', 'nawing 'container for storing roomie made from one bamboo segment', kebia 'most of the places for storing tobacco', koli, 'lontar leaves dry young (white), kebako 'tobacco', lia me'a ' red ginger', belega 'cotton (small lumps)', belaya/doi 'money', and padu 'lighting made of a mixture of cotton and resin wrapped around on a stick of wood. These are the things that make Ri'e Hikun Liman Wanan like humans.

b) Index

An index is a sign that shows the natural relationship between a sign and a causal sign. This pole is unique and unique because it is a sacred pole or a grand pillar. Ri'e Hikun Liman Wanan be analogized with a human. Thus, as a human Ri'e Hikun Liman Wanan is treated like a human. The completeness that has been mentioned on the icon is a proof of the fulfillment of the needs of a Ri'e Hikun Liman Wanan as a human being.

c) Symbol

Symbol is a sign that shows the natural relationship between the signify and signifiant. Relationships are arbitrary, relationships based on conventions (community agreements). This upright pole is a symbol that shows an inseparable vertical relationship between humans and Rera Wulan Tana Ekan. Rui'e Hikun Liman Wanan is a representation of ancestors. Ancestors are used as a mediator or a liaison between humans and Rera Wulan Tana Ekan. Ancestors will stand upright, sturdy and responsive listening to all the prayers, desires and hopes of humans and will continue to Rera Wulan Tana Ekan. If so, the behavior of acting, thinking and doing must be polite.

\section{Interpretant}

Interpretant is the interpretation of the reality that is in the sign. Interpretant of Ri'e Hikun Liman Wanan is a perpendicular shaped pole signifying an inseparable vertical relationship between humans and Rera Wulan Tana Ekan 'God'. Interpretants can be grouped into:

a) Rheme

Rheme is a sign that allows people to interpret based on choice. Ri'e Hikun Liman Wanan 'the right corner of the house ' which is equipped with attributes such as rie, kenata, ekot, wua malu, apu, gabe, tuak, neak, nawi, kebia, koli, kebako, lia me'a, belega, doi, and padu. These features allow people to interpret the traditional ritual tone in that place.

b) Dicent

Dicent is a sign in accordance with reality. The sacred pillars or sacred poles represent the ancestors as the first humans. As the first human who has given birth to a human, the ancestor will be a media liaison between humans and Rera Wulan Tana Ekan 'God'. Ri'e Hikun Liman Wanan will be equipped with facilities as mentioned in rheme.

c) Argument

Arguments are signs that directly give reasons about something. Ri'e Hikun Liman Wanan is a sacred pillar used by the Lamaholot community as a medium of communication with Rera Wulan Tana Ekan. Ri'e Hikun Liman Wanan is a representation of the ancestors so that as a form of respect for ancestral human needs needs to be met. Ri'e Hikun Liman Wanan has the following forms and meanings:

a) R'ie 'pole,pillar' 
Ri'e is a block of a certain size which is erected on the ground as a house holder. Lamaholot culture states that the pole is the shoulder on which the weight is placed. The Ri'e Hikun Liman Wanan is the upright pole to the right of the house. The selection and determination of the right pole of the house because the right means truth or good. The other meaning implied behind the right pole of the house is the meaning of the ancestral symbol, the intermediary symbol to submit a request to Rera Wulan Tana Ekan 'God', a symbol of sincerity between humans and Rera Wulan Tana Ekan 'God' that cannot be separated and the physical meaning that as the spirit/heart of the house.

b) Kenata 'bed'

Kenata 'bed' is a place to rest after tired work. Aside from being a place of rest, the reality of the 'bed' is an altar where the offerings are laid. The offerings are the giving of all things that are sincere to the ancestors with a peaceful heart. This peaceful mood is illustrated by the symbol of kenata 'bed'. As for the cultural meaning of kenata 'bed', it is as a table of offerings where all offerings are placed and a place where there is togetherness when enjoying offerings. Table offerings are a form of unity between living humans and their ancestors and Rera Wulan Tana Ekan.

c) Ekot 'container for betel nut, lime, gambier'

Ekot is a place to store betel vein, areca nut, lime and gambier. Traditional swings made by humans from palm leaf buds (palm wine). The use of young white palm leaves which have been dried and sliced to a certain size. The selection of young white palm leaves reveals a sincere heart in giving. The palm tree is the tree of life, the symbol of women. Ekot is the deepest symbol of the uterus. This illustrates the close relationship in the form of a union between women and men symbolized by betel vein and areca nut. The use of a coconut shell as a unifying container. While lime is a symbol of harmonious relations, strength and spirit. The ekot wrapped around the red color means courage.

d) Wua, malu, apu, gabe (betel nut, lime, gambier)

Betel nut 'is a parasitic plant, the leaves taste rather spicy, the fruit is long. Wua 'areca nut' is a clumped plant, trunked straight like a candle, the leaf stalk is attached to the stem shaped like a sheet of skin, the fruit is round. Gabe 'gambir' is a decoction of leaves of gambir leaves whose water is evaporated, printed in a round or square shape used as a mixture of betel nut. Gambir is an herbal medicine that has healing properties. Apu 'lime' white powder material obtained from white stones (remnants of marine organisms) which is burned is used as a mixture of betel nut. Traditionally, betel, areca nut, gambier, and lime are a form of courtesy of the Lamaholot community to the guests. Guests will be served betel nut as a form of respect. Culturally, betel is a symbol of men, areca symbol of women, lime symbol of strength that unites and gambier is the glue of a unified unity between men and women. Propositions in the Lamaholot tradition are always marked by betel nut meal.

e) Tuak 'liquor that is sliced directly from the tree'

Lontar is a type of subtropical plant that is often sliced for nira 'wine' taken. Palm tree sap hereinafter referred to as tuak. So tuak is a type of local alcohol content low. Aside from being a symbol of life, tuak is also a symbol of a binding oath/agreement for those who drink it. Tuak is always used as a drink in any ritual and before drinking it is served for Rera Wulan Tana Ekan. The Lamaholot community always prioritizes Rera Wulan Tana Ekan 'God' in any event. Before 
drinking tuak will be poured to the ground as a tribute to Rera Wulan Tana Ekan because it has created the earth that has provided a nutritious drink.

f) Neak 'saucer'

Neak is a container or 'traditional cup' from the bottom coconut shell used to fill palm wine. Coconut tree is a tall trunked palm tree, its fruit is covered in coir and hard shell, inside it contains meat containing coconut milk and water. Coconut in the Lamaholot tradition is a symbol of the human head. The head is the part of the body that is above the neck (in humans and some animals are the place of the brain, nerve center, and several sensory centers. Traditional 'cup' is always closely related to palm wine because in the traditional cup 's will be poured wine. Tuak is a symbol of breast milk (the source of life) so that the use of traditional cups is a form of respect, uphold and appreciate breast milk.

g) Nawing (container for storing wine)

Nawing is a place for storing wine, made of bamboo, the size according to the needs (volume) and only one segment so it is easy to carry. Bamboo tree is a kind of clumped, fibrous rooted with hollow, broad, hard, high stem (between 10-20 m) and is used as building material for houses and household furniture. Bamboo in the Lamaholot tradition is a male symbol that is as a protector and guardian. The symbol of breast milk stored in bamboo as a symbol of men is considered as the only container that is strong, sturdy and resilient to any threat.

h) Kebia 'container for palm leaves and tobacco'

Kebia is a kind of traditional woven material, made from palm leaves, in the form of a wallet and used to fill palm leaves and tobacco. The meaning of kebia culture is as a unifying container between tobacco as a symbol of men and palm leaves as a symbol of women.

i) Koli kebako 'cigarettes made from tobacco and palm leaves'

Koli kebako is a traditional cigarette from the Lamaholot community. Koli is lontar leaves, especially shoots of white palm leaves which have been dried, cut into pieces according to the size of a cigarette and for rolling kebako 'tobacco'. The meaning of koli kebako culture in the Lamaholot tradition is respect for guests. In the rituals, koli kebako as a form of politeness or respect for the ancestors. In addition to honoring koli kebako means brotherhood. Every brotherhood, friendship and kinship is always marked by the koli kebako tradition.

j) Lia me'a 'ginger/red ginger'

Lia 'ginger' is a taproot plant (the tubers are spicy, used as aromatic, herbs, or medicine), oval and pointed, the flowers are grainy. Based on the color, there are two types of ginger/ginger namely ginger/white ginger and red ginger / ginger. In the tradition of Lamaholot red ginger' has a very important role. The dominant ginger/ginger used is red. The red color and pedis taste are symbols of courage, strength and toughness. Ginger/red ginger is used when war occurs. Ginger/red ginger is used by chewing and then sprayed on war instruments such as spears, machetes and arrows. Lia me'a 'red ginger' is only placed in Ri'e Hikun Liman Wanan or in the traditional house of the village owner.

k) Belega 'lump of white cotton'

Belega in the form of small lumps of cotton. Belega in Lamaholot culture is always used in every traditional ritual. The meaning of white cotton culture is purity. Cotton has an important role in accordance with the rituals performed. If it is used in traditional rituals, cotton means cleansing or cleansing of sins. In connection with Ri'e Hikun Liman Wanan, tradition and thought will be placed under Ri'e Hikun Liman Wanan. The belega placed below symbolizes purity. Purity is meant is the 
Ri'e Hikun Liman Wanan is considered sacred because the Ri'e Hikun Liman Wanan has become a media of communication between humans and Rera Wulan Tana Ekan since the initial installation. Thinking means the strength, robustness and robustness of Ri'e Hikun Liman Wanan, such as rock or rock.

1) Belayaldoi 'money'

Belayaldoi 'money' is a legitimate medium of exchange or standard measure, issued by the government of a country in the form of paper, gold, silver, or other metals that are printed with certain shapes and images. Customary rituals in the tradition of the Lamaholot people use belayaldoi 'money as a means of payment. The excavation of the foundation of the house, the laying of the first stone and the installation of the Ri'e Hikun Liman Wanan in the Lamaholot tradition, belayaldoi 'money' are always placed with butter and gravel. Belaya/doi 'money' used is coins. Metal has a hard nature and is not easily destroyed in the soil so Ri'e Hikun Liman Wanan is expected to have properties like metal. Belaya/doi 'money' is used to buy land where the house is built .

m) Padu 'a mixture of resin and cotton'

$P a d u$ is traditional lighting made from a mixture of old resin seeds, the contents are taken, pounded with cotton flowers. This dough is then wrapped around a straight wooden branch so that it can be used as a light by lighting the end of the twigs that have been wrapped around the dough. The cultural meaning of this dough is the sacrifice of the sacred members themselves (cotton), and sincere sincerity (resin and twigs) to light the house especially Ri'e Hikun Liman Wanan. Symbolically Ri'e Hikun Liman Wanan is expected to be able to give themselves sincerely and sincerely to be a communication medium between humans and the Rera Wulan Tana Ekan Rera 'God'. When communicating with the Rera Wulan Tana Ekan 'God' solidly ignited as to illuminate Ri'e Hikun Liman Wanan as a place and medium of communication.

n) Prayers

In the lexicon of prayer is a request (hope, request, praise) to God. Prayer in front of Ri'e Hikun Liman Wanan states that there is a conversation or privacy communication between humans and Rera Wulan Tana Ekan 'God'. Prayers that are said or communicated are very varied such as prayers of requests or requests, prayers of hope, prayers of thanksgiving and praise, and so on.

\section{CONCLUSION}

Culture is a text about humans with all dimensions of their lives. The text about humans contains the normative life habits of a community (regulating and binding). Ri'e Hikun Liman Wanan is a cultural text about the beliefs of the people of Lamaholot on the existence of Rera Wulan Tana Ekan ' God (Supreme Being)'. Ri'e Hikun Liman Wanan is a communication medium between humans and Rera Wulan Tana Ekan 'God (Supreme Being)'. Based on the events that have been carried out it can be concluded that:

1) Rera Wulan Tana Ekan is 'God or Supreme Being)',

2) Ri'e Hikun Liman Wanan is a symbol of ancestors,

3) Ri'e Hikun Liman Wanan is a traditional ritual carried out by utilizing symbolic signs such as ri'e 'pole', kenata 'bed', ekot 'container for keeping betel nut and others', wua malu 'betel nut ', apu 'lime', gabe 'gambier ', kebia 'place for storing tobacco', koli kebako 'cigarette from palm leaves', tuak 'palm tree sap', neak 'traditional cup', nawing 'container for storing', tuak 'palm wine', lia me'a 'red ginger', belega 'wad of white cotton', belayaldoi 'money', and padu 'illuminator from resin ', and 
4) Symbolic signs in the form of cultural heritage, such as, vertical relations, communication media, table offerings, courtesy and respect, the source of life, unity and unity, strength and endurance, courage, sincerity, purity and source of light.

\section{REFERENCES}

Bebe, Boro Michael. (2012). Bau Lolon (p.77). Waibalun Flores Timur: Sekolah Tinggi Pastoran Reinha Rosari.

Hoed, H. Benny. 2008. Semiotika dan Dinamika Sosial Budaya (p. 143). Depok: Komunitas Bambu.

Kaelan. (2009). Filsafat Bahasa Semiotika Dan Hermeneutika. Jakarta: Paradigma

Muda, Yosep Padre. (2016). Ata Lamaholot (p. 93). Yogyakarta: PT Kanisius

Rukajat, Ajat. 2018. Pendekatan Penelitian Kualitatif (p. 4-6). Yogyakarta: CV Budi Utama Semenenko,Aleksei. (2012). The Texture of Culture: An Introduction to Yuri Lotman's, Semiotic Theory, (p. 22).United States: PALGRAVE MACMILLAN®

Sobur, Alex. (2009). Semiotika Komunikasi, p. 6-166. Bandung: PT. Remaja Rosdakarya

Suyanto, Bagong, Sutinah. (2011). Metode Penelitian Sosial (p.174). Jakarta: Kencana

Syamsudin, M. (2015). Konstruksi Baru Budaya Hukum (p. 26-27). Jakarta: Kencana Prenada Media Grup. 